\title{
The Impact of Credit Risk on the Financial Performance of Chinese Banks
}

\author{
Juliana Stanley Isanzu \\ School of Management, Wuhan University of Technology, China
}

\begin{tabular}{|c|c|}
\hline & ABSTRACT \\
\hline $\begin{array}{l}2017 \text { Research Leap/Inovatus Services Ltd. } \\
\text { All rights reserved. } \\
\text { DOI: } 10.18775 / \text { jibrm.1849-8558.2015.23.3002 } \\
\text { URL: } \underline{\text { http://dx.doi.org/10.18775/jibrm.1849- }} \\
\text { 8558.2015.23.3002 }\end{array}$ & $\begin{array}{l}\text { The study aim was to empirically examine the impact of credit risk on the financial } \\
\text { performance of Chinese banks. Secondary data was collected from five largest commercial } \\
\text { banks in the country for the period of } 7 \text { years from } 2008 \text { to 2014. The study used } \\
\text { nonperforming loans, capital adequacy ratio, impaired loan reserve, and loan impairment } \\
\text { charges as measures of credit risk and for a measure of financial performance return on asset } \\
\text { was used. Data analysis was done using a balanced panel data regression model, and the study }\end{array}$ \\
\hline $\begin{array}{l}\text { Keywords: } \\
\text { China; } \\
\text { Credit risk; } \\
\text { Financial performance; }\end{array}$ & $\begin{array}{l}\text { findings reveal nonperforming loan and Capital adequacy have a significant impact of on } \\
\text { financial performance of Chinese commercial banks; therefore, the need to control credit risk } \\
\text { is crucial for bank financial performance. }\end{array}$ \\
\hline
\end{tabular}

Banks.

\section{Introduction}

The Management of the risk-return tradeoff is imperative for the banks to maintain their profitability. Since their core activity is credit creation, this renders credit risks inevitable. As a result, credit risk is among the core risks related to the bank main income generation activity. According to a Feb. 13 China Banking Regulatory Commission report, credit risks has been observed to continue to increase for Chinese banks through 2014, with nonperforming loans of the country's commercial banks increasing from 250.6 billion Yuan to 842.6 billion Yuan from the previous year. However, the regulator still assures the public that banks' asset quality was still under control.

It should be noted that it is an established fact in many literature of banking that the losses of many banks are a result of the Non-Performing Loans. Increases in NPLs rate are often associated with the failure of the bank's credit policy. It is also evident that the financial crisis which occurred in the US in the late 2000s and spread in most parts of the world was indeed a result of default on loans and mortgages. Although, the major causes of bad debts are the failure of borrowers to pay back, which is often caused by the uneconomic use of loans, high-interest rate and low per capita income. Extra flexible credit rationing policy can also be a source high NPLs rate in the midst of the high competitive banking environment of today's world. Hence, it is clear why banks need to manage credit risk which is mainly from NPLs as it is very crucial for banks survival and profitability.

Credit risk according to Basel Committee of Banking Supervision BCBS (2001) is the possibility of losing the outstanding loan partially or totally, due to credit events (default risk). Credit events usually include events such as bankruptcy, failure to pay a due obligation, repudiation/moratorium or credit rating change and restructure. Basel
Committee on Banking Supervision- BCBS (1999) defined credit risk as the potential that a bank borrower or counterparty will fail to meet its obligations in accordance with agreed terms.

Banks generate income mainly through credit creation, which also results in huge risks to the lender and the borrower. The smooth functioning of the bank can be greatly jeopardized by a failure of the trading partner to fulfill their contractual obligation in due date. A bank with a high credit risk has high bankruptcy risk that puts the depositors in jeopardy. Interest rates charged by banks are fast overtaken by inflation and borrowers find it difficult to repay loans in unstable economic environments because real income falls, leading to increased insider loans and over-concentration in certain types portfolios giving rise to credit risk. But in a bid to survive and maintain profits in this highly competitive environment, banks have the tendency to take unnecessary risks. In 1994, many bank failures occurred in Mexico, 1980s banking crises in Kenya and 1990s in Spain were attributed to lack of experience, improper lending practices, increasing the tendency for greater risk taking and organization, and lack of information systems to adequately assess credit risk in the falling economy.

\section{Literature review}

Noman. A et al (2015) Study was to find the effect of credit risk on the profitability of Bangladesh banks. The study used an unbalanced panel data and 172 observations from 18 private commercial banks from 2003 to 2013. The study uses NPLGL, LLRGL, LLRNPL and CAR as credit risk indicators and ROAA and ROAE and NIM as profitability indicators. Using OLS random effect model, GLS and system GMM the study finds a robust negative and significant effect of NPLGL, LLRGL on all profitability indicators. The results showed a negative and significant effect of CAR on ROAE. The results also revealed that the effect of the 
implementation of Basel II is significantly positive on NIM but significantly negative on ROAE.

Kipngetich and Muturi (2015) study focused on assessing the effect of credit risk management on the financial performance of SACCOs with specific reference to SACCOs in Bomet County. SACCOS remain the most important players in the provision of financial services and have deeper and extensive outreach than any other type of financial institution. They provide savings, credit and insurance services to a large portion of the Kenyan population. SACCOs have contributed to a large extent to the continuous economic development in Kenya, by offering financial services to the poor and small scale businesses. However, the growth of SACCOs has been inhibited by several challenges relating to effective credit risk management strategies. The dependent variable used was a financial performance of the SACCOs while the independent variables were comprised of Capital adequacy and Management efficiency. The sample size for 18 SACCOs was selected to participate in the study. All the predictor variables (CAR, and ME) had a positive relationship with financial performance. The CAR coefficient of the predictor variables was significant at $5 \%$ level of significance except for ME. The findings confirm that there is a statistically significant influence of CAR on the financial performance of SACCOs.

Raad M.L (2015) The study aimed at adding knowledge on how CRM practices help to increase profitability and long-term sustainability of commercial banks. Credit risk management covers identification, measurement, matching mitigation, monitoring and control of the credit risk exposures. The researcher used secondary data relating to the financial status of Basic Bank Ltd and did a comprehensive overview about CRM in a different phase of the report. First a description of CRM practice and performance of BBL. Then analyzed the impact of CRM on the financial performance of the bank. The researcher used MS Excel as well as SPSS software to establish a relationship between CRM and banks profitability. Findings revealed that credit risk management for banking is vital since banks make a profit from their credit disbursement. Effective CRM proved to help increase the present and future financial performance of the bank. The relationship between CRM and Banks profitability was found to be positive thus effective CRM contributes to Banks financial performance.

Perhaps the most compelling rationale for the researcher to pursue credit risk is because it causes variability of profits which leads to a reduction in the bank's earnings. Significant loss of earnings can lead to stakeholders losing confidence in the bank's operations, it also reduces credit available for prospective loan applicants, compromises the bank's liquidity and causes failure to meet its obligations and subsequent loss of the strategic bank position in the industry. Sometimes it can cause the withdrawal of license or charter and even bankruptcy. It is for this reason that the study aims to investigate the impact of credit risk on bank's financial performance to help understand the effect, solidify the need for allocating time and resources for effective credit risk management.

\section{Research problem and objectives}

It is not doubted that innovation and in general research and the nature of the banking business is very sensitive because more than $85 \%$ of their liabilities are customer's deposits (Saunders, Cornett, 2005). Banks then use these deposits to generate credit for their borrowers, which is the main revenue generating activity for most banks. With the increase of credit transactions and loan customers in the nation's economy, credit expansion is inevitable. The trend in the sector shows growing bank deposit-loan ratio as the economy grows but unfortunately so is credit risk growth. Traditionally, credit was made available in association with one's financial status, business sustainability, reputation, and liquidity, but the unpredictable market situations make it difficult for banks to rely on these determinants. Business conditions are often unpredictable and can lead to changes in the borrower's financial position thus affecting their ability the repay the loans.

The impact of Credit risk on financial performance has been a topic of interest to many scholars since credit risk has been identified as one of the major factors known to impact the financial performance of banks. Amongst others who have carried out extensive studies on the topic, their results have not been in consensus. While others found credit risk to impact positively on bank's financial performance, others found a negative relationship and others asserted that other factors apart from credit risks which impact on bank's performance because they did not find convincing evidence otherwise. The overall objective of the study is to investigate the impact of credit risk on the financial performance of five major Chinese banks which aims to provide managerial and policy implications but also a contribution to existing literature on the subject matter. The study will answer the specific research questions:

Is there a significant relationship between Non-Performing Loans and financial performance of Chinese banks?

Is there a significant relationship between Capital Adequacy and financial performance of Chinese banks?

Is there a significant relationship between Impaired Loan Reserves and financial performance of Chinese banks?

Is there a significant relationship between Loan Impairment Charges and financial performance of Chinese banks?

\section{Data and Methodology}

The study adopted a similar model as used by Gizaw et al 2015 where ROA will be used as a measure of financial performance the dependent variable, the independent variable credit risk will be measured by Nonperforming loan ratio, Capital Adequacy ratio, impaired loan reserve, and loan impairment charges, which were found to be suitable for the country of study and also data availability according to the reporting standards. Bank financial statement for the time period of 2008-2014 from the bank's website was be used to obtain the data for the variables.

The model: ROA $=\beta_{0}+\beta_{1} \mathrm{NPL}+\beta_{2} \mathrm{CAR}+\beta_{3} \mathrm{IMPLR}+\beta_{4} \mathrm{LIMPC}+\mathrm{e}$ Where $\beta_{0}$ is a constant term, $\beta_{1}-\beta_{4}$ coefficients of independent variables ROA is a dependent variable net income / total asset

NPL is Non-performing loan ratio

CAR is Capital Adequacy ratio

IMPLR is impaired loan reserve ratio

LIMPC is loan impairment charges

Return on Assets is the measure of efficiency; it determines how well the bank uses its scarce resources to generate profits. It is the ratio of net income to the total asset. The higher the ratio is an indication of a better financial performance. It was also used in similar studies by Francis 2013, Athanasoglou et al. (2008); Perera et al. (2013).

Nonperforming loans to gross loan (NPL) as credit risk indicators as used by Kolapo et al., 2012; Rajan \& Dhal, 2003; Samad, 2004. It measures the percentage of gross loans that are nonperforming or doubtful in banks' loan portfolio. It is considered as one of the most important indicators of credit risk and loan quality the bank. Lower the ratio is the indication of better asset quality and lowers doubtful loan, therefore, lower credit risk and the better the financial performance. 
Capital adequacy ratio (CAR) also used by Francis (2013); Masood and Ashraf (2012); Perera et al. (2013) is recommended by Basel accord for judging asset quality and prudent credit risk management. It is the ratio of total capital to risk adjusted assets of the bank. The higher the ratio is the indication of adequacy of the bank's capital and better assets quality, therefore, low credit risk. This is also an independent variable and is chosen because it is the core measure of a bank's financial strength from a regulator's point of view. It consists of the types of financial capital considered the most reliable and liquid, primarily shareholders' equity. Banks with good Capital Adequacy Ratio have good financial performance.

Impaired loan reserve ratio to gross loan (IMPLR) as credit risk indicators as used by Boahene et al. (2012); Kolapo et al. (2012); Samad (2004). This ratio measures the percentage of gross loan which has been set side but not yet charged off. Historically higher the ratio is the indication of weak loan portfolio management quality and high credit risk.

Loan Impairment Charge to gross loan (LIMPC) as a measure of credit risk shows the percentage of loans which have been charging off as impaired loans thus has an impact on the financial performance as it reduces the profitability of the bank. The ratio shows the irrecoverable impaired loans and the higher ratios shows inefficiency and high credit risk faced by the bank.

\section{Findings and Discussion}

Table 1 presents the descriptive statistics of the variables used in the study, the four measures of credit risk indicator which are the ratio of NPL, CAR, IMPLR, LIMPC and the measure of financial performance ROA.

\begin{tabular}{|l|l|l|l|l|l|}
\hline \multicolumn{7}{|c|}{ Table 1: Descriptive Statistics } \\
\hline & $\mathrm{N}$ & Min. & Max. & Mean & Std. Deviation \\
\hline roa & 35 & .8200 & 1.4600 & 1.1931 & .16820 \\
\hline npl & 35 & .8500 & 4.3200 & 1.4511 & .72112 \\
\hline car & 35 & 3.8600 & 7.5600 & 6.2248 & .87218 \\
\hline implr & 35 & 2.0500 & 4.4600 & 2.7117 & .67143 \\
\hline lichgl & 35 & .2900 & 1.2200 & 0.6262 & .26092 \\
\hline $\begin{array}{l}\text { Valid N } \\
\text { (listwise) }\end{array}$ & 35 & & & & \\
\hline
\end{tabular}

All commercial banks are required to follow regulations of central bank regarding different statutory issues of risk management. It is evident from the low standard deviations that credit risk management quality is similar among the used banks. The nonperforming loan ratio has a maximum value of 4.3 to minimum of 0.85 percent with the mean and standard deviation 1.45 and 0.72 respectively which indicates there is low volatility among the ability of banks to manage credit risk. The minimum capital adequacy ratio is 3.86 percent with is lower than regulatory requirement of 10 percent which means there are some banks which are noncompliance as they have not been reaching the required level of Basel II standards. The Impaired loan reserve ratio has a minim of 2.05 and a maximum of 4.46 with a standard deviation of 0.671 which is also low. The Loan impairment charges are very low which is desirable since it represents the actual loan charge-off, as it is evident with the minimum of 0.29 and a maximum value of 1.2 with a low standard deviation of 0.6 signifying a low variation among banks. The measure of financial performance ROA has a minimum value of 0.82 and a maximum of 1.4 with a very low standard deviation of 0.168 which is evident that the performance among banks is nearly similar.
Table 2: Results of the Regression Analysis

\begin{tabular}{|l|l|l|l|l|}
\hline Variable & Coefficient & Std. Error & t-Statistic & Prob. \\
\hline C & 0.951014 & 0.110405 & 8.613838 & 0.0000 \\
\hline NPL & -0.100689 & 0.020561 & -4.897053 & 0.0000 \\
\hline CAR & 0.061692 & 0.020931 & 2.947407 & 0.0067 \\
\hline IPLRESERV & -0.005743 & 0.028358 & -0.202512 & 0.8411 \\
\hline LICHARGE & 0.031600 & 0.086913 & 0.363583 & 0.7191 \\
\hline \multicolumn{5}{|c|}{ Weighted Statistics } \\
\hline R-squared & 0.903090 & Mean dependent var & 1.474038 \\
\hline $\begin{array}{l}\text { Adjusted } \\
\text { squared }\end{array}$ & R- & 0.873272 & \multicolumn{3}{|l}{ S.D. dependent var } & 0.708524 \\
\hline $\begin{array}{l}\text { S.E. } \\
\text { regression }\end{array}$ & 0.066985 & \multicolumn{5}{|l}{ Sum squared resid } & 0.116661 \\
\hline
\end{tabular}

Adjusted R-squared is coefficient is used to tell us the amount of variation in the dependent variable which is due to changes in the independent variable. From the findings in the table above the value of adjusted Rsquared is 0.873 , indicating that there was variation of 87.3 percent on the financial performance of Chinese banks due to changes in nonperforming loans, capital adequacy, Impaired loan reserve ratio and Loan Impairment Charge at a 95 percent confidence interval. $\mathrm{R}$ is the correlation coefficient which shows the strength of the relationship between the study variables which in our case is 0.90 which shows a strong relationship between the study variables.

As expected relationship between nonperforming loan ratio and financial performance is found to be negative and significant indicating that high nonperforming loan reduces the bank's ROA. Keeping other repressors constant, the results show that one unit rise in nonperforming loan decreases returns on assets by 0.10 units. Other researchers who also found a negative impact includes Kolapo et al. (2012) and Ruziqa (2013).

Capital adequacy is said to increase the strength of the bank which improves the capacity of the bank to buffer or absorb impaired loan losses and ensure the bank can continue to run efficiently as a going concern. The results show that capital adequacy was found to have a positive and significant effect on return on assets. Keeping other repressors constant, the results show that one unit rise in capital adequacy increases returns on assets by 0.06 units. Similar results were also found by Kosmidou, et al 2005 and Gizaw, 2015. The findings reveal that Chinese commercial banks depend on the equity capital as the source of funding and it is used to enhance profitability which is evident by the increase in financial performance.

The effect of impaired loan reserve to gross loan on return on asset was also found to be negative as by Kolapo et al., 2012 and Sufian, 2009 because as banks use more profit as a buffer against their impaired loans the profitability will also reduce. The beta coefficients of impaired loans reserve ratio indicate that keeping other variables constant a unit increase in the ratio decreases return on assets by 0.006 unit.

The effect of the ratio of loan impairment charges on ROA is found to be positive. The results reveal that a unit increase in loan impairment charges leads to an increase in financial performance by 0.03 units while keeping other variables constant. This means that Chinese banks have been able to find a way to keep the impaired loans charges to gross loan ratio within a rate that is enhancing its profitability. Some of the impaired loans actually get recovered before they are written off as bad debts which 
increase financial performance. This was evident from the low levels found in the banks of this ratio.

\section{Conclusion and Suggestions}

Credit creation being the main activity of the bank is inevitable, and it also exposes the bank to credit risk. By employing panel data regression analysis, the study aimed to find the impact of credit risk on the financial performance of major Chinese banks for eight years. The results revealed that credit risk management has improved over the past years as prudential techniques have been used to reduce the negative impact of credit risk on the financial performance of banks. The study found nonperforming loans and capital adequacy as measures of credit risk to have a significant impact on financial performance. Hence managers should pay more attention to improving capital adequacy since it positively enhances financial performance while reducing nonperforming loans by applying modern strategies and techniques for credit risk management.

\section{References}

- Achsania Ruziqa (2013). The Impact of Credit and Liquidity Risk on Bank Financial Performance: The Case of Indonesian Conventional Bank with Total Asset above 10 Trillion Rupiah: International Journal of Economic Policy in Emerging Economies, Vol.6 (2), pp.93 - 106, CrossRef

- Athanasoglou, P.P, Brissimis, S.N, and Delis, M.D (2008). BankSpecific, Industry-Specific and Macroeconomic Determinants of Bank Profitability: Journal of International Financial Markets, Institutions and Money, 2008, Vol. 18 (2):121-136, CrossRef

- Abu Hanifa Md. Noman, Sajeda Pervin, Mustafa Manir Chowdhury \& Hasanul Banna(2015). The Effect of Credit Risk on the Banking Profitability: A Case on Bangladesh Global Journal of Management and Business Research: Vol.15 (3)

- Boahene, S. H., Dasah, J., \& Agyei, S. K. (2012). Credit Risk and Profitability of Selected Banks in Ghana: Research Journal of Finance and Accounting, 3(7), 6-14

- Francis, M. E. (2013). Determinants of Commercial Bank Profitability in Sub-Saharan Africa: International Journal of Economics and Finance, 5(9), p134.

- Gizaw (2015). The Impact of Credit Risk on Profitability Performance of Commercial Banks in Ethiopia: African Journal of Business Management, Vol.9 (2), pp. 59-66

- Heffernan, S., \& Fu, M (2008). The Determinants of Bank Performance in China. Available at SSRN 1247713, CrossRef

- Hassan, A. Al-Sharkas, A. Samad, (2004). An Empirical Study of Relative Efficiency of The Banking Industry in Bahrain, Studies in Economics and Finance, Vol. 22 Issue: 2, pp.40-69, CrossRef

- Kipngetich S., and Muturi, W (2015). Effect of Credit Risk Management on Financial Performance of Savings and Credit CoOperative Society in Kenya: Strategic Journal of Business and Change Management, Vol. 2 (4)

- Kolapo, T.(2012). Credit Risk and Commercial Banks' Performance in Nigeria: A Panel Model. Approach: Australian Journal of Business and Management Research Vol 2 (2) [31-38]

- Kosmidou, K. , Tanna, S. and Pasiouras, F. (2008). Determinants of Profitability of Domestic UK Commercial Banks: Panel Evidence from the Period 1995-2002: Economics Finance and Accounting Applied Research Working Paper Series no. RP08 - 4. Coventry: Coventry University.

- Masood, O., \& Ashraf, M. (2012). Bank-specific and Macroeconomic Profitability Determinants of Islamic, CrossRef
- Perera, S., Skully, M., \& Chaudhry, Z. (2013). Determinants of Commercial Bank Profitability: South Asian Evidence: Asian Journal of Finance \& Accounting, 5(1), 365-380.

- Raad Mozib Lalon (2015). Credit Risk Management (CRM) Practices in Commercial Banks of Bangladesh: A Study On Basic Bank Ltd.: International Journal of Economics, Finance and Management Sciences Vol 3(2): 78-90, $\underline{\text { CrossRef }}$

- Samad, A. (2004). Performance of Interest-free Islamic Banks visà-vis Interest-based Conventional Banks of Bahrain: International Journal of Economics, Management and Accounting, Vol 12(2).

- Samuel Hymore Boahene, Julius Dasah, Samuel Kwaku Agyei (2012). Credit Risk and Profitability of Selected Banks in Ghana research journal of finance and accounting Vol 3(7)

- Sufian, F. (2009). Determinants of Bank Efficiency during Unstable Macroeconomic Environment: Empirical Evidence from Malaysia. Research in International Business and Finance, 23(1), 54-77, CrossRef 